Our Nature (2012) 10: 61-70

\title{
Extensive Net Cage Culture of Nile Tilapia (Oreochromis niloticus) Fingerlings in Nutrient-enriched Pond
}

\author{
W. Jiwyam \\ Program of Fisheries, The School of Science and Technology, Nong Khai Campus, Khon Kaen University, Nong \\ Khai Province, Thailand \\ E-mail:wirjiw@kku.ac.th
}

\begin{abstract}
To investigate the potential of extensive net cage culture for Nile tilapia (Oreochromis niloticus) fingerlings, an experiment was conducted in net cages suspended in a fertilized pond. Mixed-sex population of Nile tilapia with an average initial body weight of $0.065 \mathrm{~g}$ was used to stock in experimental cages. Four treatments; non added-substrate without supplemental feeding (NSNF), non added-substrate with supplemental feeding (NSAF), added-substrate without supplemental feeding (ASNF), and added-substrate with supplemental feeding (ASAF) were tested. The results indicated that addition of substrates which gave an additional submerged surface area of approximately equal to the total cage surface area did not show significant effect on the growth $(\mathrm{p}>0.05)$. The fish gross yield obtained from non added-substrate cages without supplemental feeding was $1.22 \mathrm{~kg} / \mathrm{m}^{3}$ for a 56 -day period.
\end{abstract}

Key words: Wastewater treatment, periphyton-based aquaculture, fish nursing, communal water resource, sustainable aquaculture

\section{Introduction}

Studies have shown that adding artificial substrates for periphyton growth in pondbased culture systems can increase the production of some cultured species (Hem and Avit, 1994; Wahab et al., 1999; Ramesh et al., 1999; Azim et al., 2001a; Azim et al., 2001b; Keshavanath et al., 2001a; Keshavanath et al., 2004). Consequently, the provision of substrates could reduce the need for supplemental feeding and that substrates had positive effect on fish survival (Keshavanath et al., 2002). More specifically, periphyton may be an alternative or a complement for supplementary feed in fingerling production (Keshavanath et al., 2004). However, most previous studies were conducted in aquaculture pond systems, while those few studies that were conducted in cage conditions still have some recommendations for further studies (Huchette et al., 2000; Huchette and Beveridge, 2003).

Even though experiments have demonstrated that fish production from ponds having periphyton substrates is higher than that from substrate-free controls (Hem and Avit, 1994; Wahab et al., 1999; Keshavanath et al., 2001b; Azim et al., 2002a; Azim et al., 2002b), production results with tilapia in periphyton systems have been mixed (Keshavanath et al., 2004). High production was reported in acadja systems in West Africa with blackchin tilapia (Sarotherodon melanotheron; Hem and Avit, 1994), but no significant effect of periphyton was found in an experimental 
system with Nile tilapia (Oreochromis niloticus; Shrestha and Knud-Hansen, 1994; Norberg, 1999). Uddin (2007) noted that the addition of periphyton substrates resulted in higher Nile tilapia production. However, these are all the results from pond-based systems. In addition to grazing on phytoplankton they feed on benthic and attached algal and detritus (Bowen, 1981; 1982), therefore a wide range of feeding habits and sources of food availability in pond systems may lead to mixed production results of tilapias. Moreover, the previous studies of periphyton-based cage culture concerned grow-out production, which seems to require higher periphyton production in each culture unit in comparison with early or even advanced nursing in cages. Consequently, it remains to be demonstrated whether periphyton grazing is a significant and cost effective means of increasing the food supply for the production of tilapia fry and fingerling stages in cages (Huchette et al., 2000).

In Thailand, the demand for Nile tilapia fingerlings is increasing along with the use of cage culture; however, the supply of adequately sized fingerlings tends to be a major constraint. Many cage farms now prefer to be stocked by larger sized fingerlings as their shortened grow-out period means lower feed costs and less susceptibility to adverse culture environment risks. To supply this demand, many farm ponds are being used to raise Nile tilapia fingerlings at the nursing stage; however, problems have been encountered over the quality and size variations of the fingerlings as well the high levels of mortality due to harvesting techniques. To address the issues of quality and size and thus improve the efficiency of these nursing systems, the use of net cages with added substrates in nutrient enriched water is of interest. If the addition of artificial substrates in cages can increase growth when compared to free-substrate controls, it would be an alternative choice for fingerling production. Furthermore, if daily feeding is considered a laborious management practice in fish fry nursing, then a substrate-based cage system would be more practical. However, the use of net cage culture in nutrient enriched ponds or other water bodies would be both eco-friendly and a low-cost aquaculture technique.

Therefore, the purpose of this study was to determine the growth performances of Nile tilapia fingerlings cultured in net cages suspended in nutrient-enriched pond under different management practices.

\section{Materials and methods}

The experiment was carried out during February to April 2010 at the Nong Khai Campus of Khon Kaen University in Thailand's Nong Khai province. Square net cages made of blue nylon netting with a 1$\mathrm{mm}$ mesh size and measuring $1 \times 1 \times 1.2 \mathrm{~m}$, were used as experimental units. The submerged volume of each cage was $1 \mathrm{~m}^{3}$. All were suspended from a bamboo structure in a $400-\mathrm{m}^{2}$ fertilized fish pond. Added-substrates cages were provided with bamboo poles (mean diameter $5 \mathrm{~cm}$, length $50 \mathrm{~cm}$ ) which were hung and suspended vertically into the cages, at a total density of 13 poles per cage, and which give an additional submerged surface area approximately equal to the total cage surface area.

Prior to the experiment, the pond was renovated, and all larger aquatic animals were eradicated by frequent netting. It was then treated with lime $\left(\mathrm{CaCO}_{3}\right)$ at the rate of $250 \mathrm{~kg} / \mathrm{ha}$. After 1 week of liming, it was 


\section{W. Jiwyam / Our Nature (2012) 10: 61-70}

then fertilized with cow manure, urea and triple super phosphate (TSP) at the rate of 2000,100 and $100 \mathrm{~kg} / \mathrm{ha}(80,4$, and $4 \mathrm{~kg}$ per $400 \mathrm{~m}^{2}$-pond), respectively. It continued thereafter to be fertilized at fortnightly intervals at a half of the initial rate (40, 2 and $2 \mathrm{~kg}$ per pond). The cow manure was applied at the four corners of the pond, while the urea and TSP were soaked together with water for 6 hours and then spread over the water surface. On the same day of the first fertilization, bamboo poles were suspended into the added-substrate cages. The cages were left for 10 days to allow plankton development in the water column and periphyton growth on bamboo poles, and the stocked with the fish.

Four treatments; non added-substrate without supplemental feeding (NSNF), non added-substrate with supplemental feeding (NSAF), added-substrate without supplemental feeding (ASNF), and addedsubstrate with supplemental feeding (ASAF) were tested. A mixed-sex population of Nile tilapia, $O$. niloticus fries (individual weight $0.065 \mathrm{~g}$ ) were stocked at 500 fish per cage $\left(1 \mathrm{~m}^{3}\right)$. Each treatment was tested in triplicate. Experimental fish were stocked after 10 days of substrate installation, and fish from all treatments were harvested after 56 days. Supplementary feed was a 2:1 ratio mixture of local rice bran and fish meal. Crude protein content of the mixture was analyzed (AOAC, 2005) and the average value was $27.7 \%$. Supplementary feed was manually delivered 2 times, 09:00 and 16.00 $\mathrm{h}$ daily at $10 \%$ body weight of the fish throughout the experimental period. The feed was adjusted biweekly based on the bulk weight of the fish estimated from a sample of 25 individuals.

All the fish were weighed at the beginning and end of the experiment. The final average weight $(\mathrm{g})$ of the individual fish in each cage was estimated by dividing the total final biomass in the cage by the number of survivors. Total weight increments (net yield) were estimated by deducting the biomass stocked from the biomass harvested and was expressed as $\mathrm{kg} / \mathrm{m}^{3}$. The specific growth rate $(\% / \mathrm{d})$ was calculated as: $\left(\ln W_{2}-\ln W_{1}\right) / \mathrm{t} \times 100$, where $W_{1}$ is the initial live body weight $(\mathrm{g}), W_{2}$ is the final live body weight ( $\mathrm{g}$ ) and $t$ is the time in days. Survival rate (\%) was calculated as: (no. of fish harvested/no. of fish stocked) x 100.

The water quality in the experimental cages and pond was monitored fortnightly between 09:00 and 10:00 $\mathrm{h}$ on each sampling day with the water temperature and dissolved oxygen (YSI model 52), and $\mathrm{pH}$ and conductivity (Hach model sension 5 ) being recorded. Water samples from the experimental cages and pond were collected fortnightly and analyzed for chlorophyll $a$ (acetone extraction), total ammonia nitrogen (phenate method), nitrite-N (diazotization), nitrate (cadmium reduction and diazotization), soluble reactive phosphorus (ascorbic acid method) and total phosphorous (persulfate digestion and ascorbic acid finish) according to Standard Methods for the Examination of Water and Wastewater (APHA, 1989). Total alkalinity and total hardness from the experimental cages were measured at monthly intervals (APHA, 1989).

After 10 days of substrate installation, periphyton samples were collected and thereafter continued to be taken at fortnightly intervals. For each sampling time, one pole from each cage was selected randomly. From each pole, one sample (a 10 $\mathrm{x} 10 \mathrm{~cm}$-band of periphyton) was taken at the middle depth $(50 \mathrm{~cm}$ beneath water 
surface) for dry matter and ash-free dry matter contents analyses. After collection of the periphyton samples, the poles were returned to their original position and marked so that sampled poles were always excluded from subsequent samples. Dry matter (DM) was determined by drying the samples overnight at $105{ }^{\circ} \mathrm{C}$ to a constant weight, upon which ash content was determined using a muffle furnace $(4 \mathrm{~h}$ at $\left.540{ }^{\circ} \mathrm{C}\right)$. The final weight of the crucible along with the remains was weighed for calculation of the ash and ash-free dry matter (AFDM).

The data on final mean weight, specific growth rate and survival rate were compared using analysis of variances (ANOVA) and Tukey-HSD test. The assumptions of normal distribution and homogeneity of the variances were checked before analyses. The differences were considered statistically significant at an alpha level of 0.05 . Variations of treatment means are presented in "mean \pm standard deviation".

\section{Results}

Table 1 shows growth and survival of Nile tilapia from all treatments for a 56-d nursing period of the experiment. Survival was not significantly different among treatments $(\mathrm{p}$ $>0.05$ ), and was higher than $83 \%$. Adding substrates did not affect on growth ( $p>$ 0.05 ), while supplementary feed showed significant effect on growth $(\mathrm{p}<0.05)$. The higher specific growth rate of the fish obtained from cages provided with supplementary feed but no significant difference was observed between added and non-added substrate cages. Fish yields were significantly higher in cages provided with feed either with substrate or without substrate $(\mathrm{p}<0.05)$.
There was no significant difference in periphyton biomass (DM or AFDM) between ASNF and ASAF treatments for each sampling day $(\mathrm{p}>0.05)$. Periphyton biomass tended to decrease rapidly after fish stocking and then after the 2 nd week of experiment was relatively stable and less likely to fluctuate (Fig. 1 and 2). Periphyton biomass in dry matter or ash free dry matter of ASNF and ASAF treatments decreased significantly after fish stocking $(\mathrm{p}<0.05)$. The average dry matter periphyton of the two treatments before, and two weeks after, fish stocking were approximately 0.622 and $0.286 \mathrm{mg} / \mathrm{cm}^{2}$, respectively. Average periphyton dry matter or as free dry matter between ASNF and ASAF treatments throughout the culture period was not significantly different $(\mathrm{p}>0.05)$. The average values are summarized and given in Table 2.

The water quality parameters measured during the experiment were summarized and given in table 3 . For each water quality parameter, there was no significant difference between treatments and open pond water during experiment. Average chlorophyll $a$ concentrations measured in cages of all treatments tended to increase after the 2nd week of the experiment (Fig. 3 ). The average chlorophyll $a$ concentration measured in cages was $131.56 \pm 103.70 \mu \mathrm{g} / \mathrm{L}$

\section{Discussion}

All the water quality parameters in experiment were within the acceptable ranges, as recommended for tropical aquaculture (Boyd, 1982; Boyd and Tucker, 1992; Beveridge, 1996). There was no interaction effect between the addition of substrates and supplementary feed on the growth parameters of the fingerlings. The 


\section{W. Jiwyam / Our Nature (2012) 10: 61-70}

addition of substrates alone did not show significant effect on the growth, while supplementary feeding could improve growth of the fish in added or non-added substrate cages. The results indicate that periphyton production can not replace or

Table 1. Growth parameters of Nile tilapia fry over a 56-day period in cages. All values are means \pm SD.

\begin{tabular}{lllll}
\hline \multicolumn{1}{c}{ Growth parameters } & \multicolumn{4}{c}{ Treatments } \\
\cline { 2 - 5 } & \multicolumn{1}{c}{ NSNF } & NSAF & ASNF & ASAF \\
\hline Harvest (no. fish) & $414 \pm 58.07$ & $457 \pm 4.041$ & $477 \pm 15.14$ & $459 \pm 7.07$ \\
Final mean weight $(\mathrm{g})$ & $3.00 \pm 0.51^{\mathrm{a}}$ & $5.43 \pm 1.15^{\mathrm{b}}$ & $2.81 \pm 0.26^{\mathrm{a}}$ & $5.24 \pm 0.26^{\mathrm{b}}$ \\
Specific growth rate $(\% / \mathrm{d})$ & $6.82 \pm 0.30^{\mathrm{a}}$ & $7.87 \pm 0.38^{\mathrm{b}}$ & $6.71 \pm 0.17^{\mathrm{a}}$ & $7.83 \pm 0.08^{\mathrm{b}}$ \\
Survival $(\%)$ & $82.87 \pm 11.61$ & $91.47 \pm 0.81$ & $95.47 \pm 3.03$ & $91.80 \pm 1.41$ \\
Gross yield $\left(\mathrm{kg} / \mathrm{m}^{2}\right)$ & $1.22 \pm 0.07^{\mathrm{a}}$ & $2.49 \pm 0.55^{\mathrm{b}}$ & $1.34 \pm 0.10^{\mathrm{a}}$ & $2.41 \pm 0.08^{\mathrm{b}}$ \\
Net yield $\left(\mathrm{kg} / \mathrm{m}^{2}\right)$ & $1.19 \pm 0.07^{\mathrm{a}}$ & $2.45 \pm 0.55^{\mathrm{b}}$ & $1.31 \pm 0.10^{\mathrm{a}}$ & $2.37 \pm 0.08^{\mathrm{b}}$ \\
\hline
\end{tabular}

Mean values with different letters in the same row are significantly different $(p<0.05)$ by Tukey-HSD.

Table 2. Average periphyton biomass in dry matter (DM) and ash free dry matter (AFDM) throughout a 56-day period $(\mathrm{n}=15)$. All values are means \pm S.D. (range).

\begin{tabular}{ccc} 
& $\mathrm{DM}\left(\mathrm{mg} / \mathrm{cm}^{2}\right)$ & $\mathrm{AFDM}\left(\mathrm{mg} / \mathrm{cm}^{2}\right)$ \\
\hline ASNF & $0.333 \pm 0.163(0.126-0.622)$ & $0.111 \pm 0.057(0.041-0.246)$ \\
AS AF & $0.373 \pm 0.217(0.065-0.872)$ & $0.126 \pm 0.117(0.008-0.470)$ \\
\hline
\end{tabular}

Mean values with different letters in the same column are significantly different (Tukey HSD).

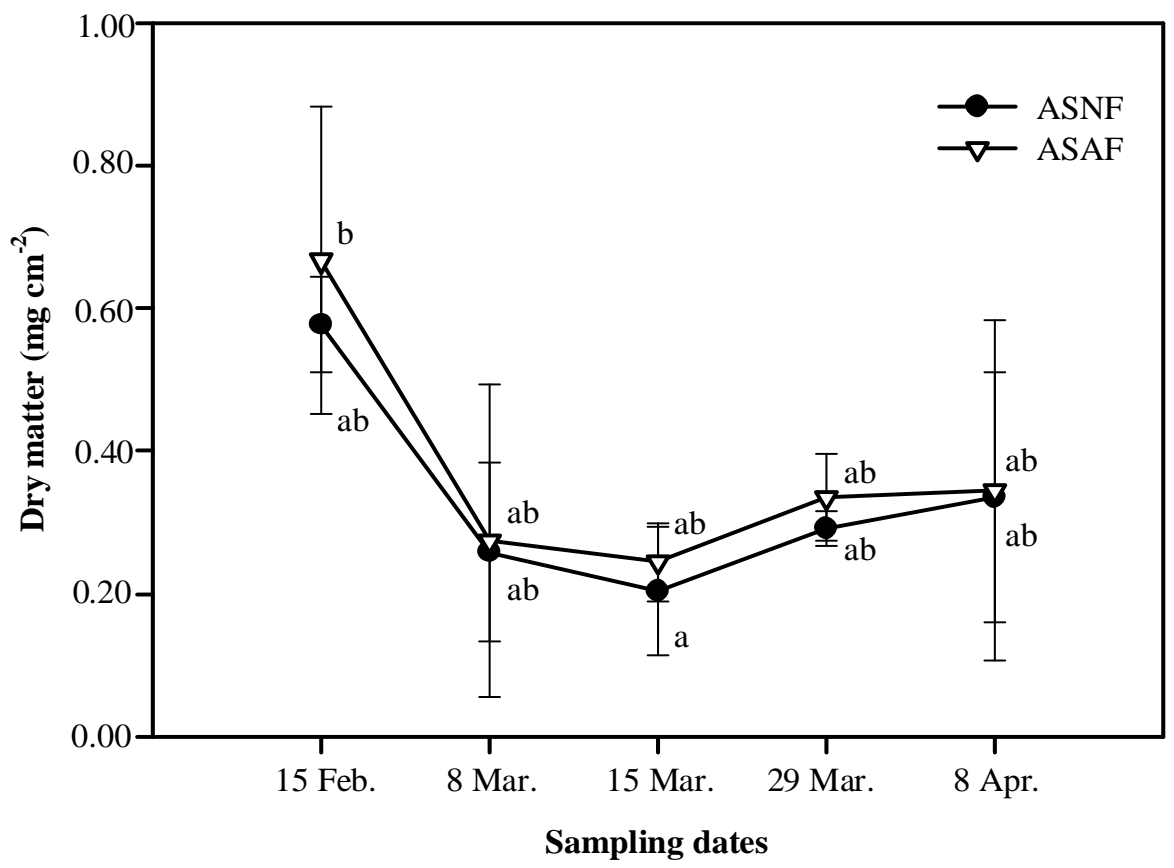

Figure 1. Average periphyton dry matter during the experimental period. Values are the means $\pm \mathrm{SD}$ ) of three replicated cages per sampling date $(n=3)$ in each treatment. 
W. Jiwyam / Our Nature (2012) 10: 61-70

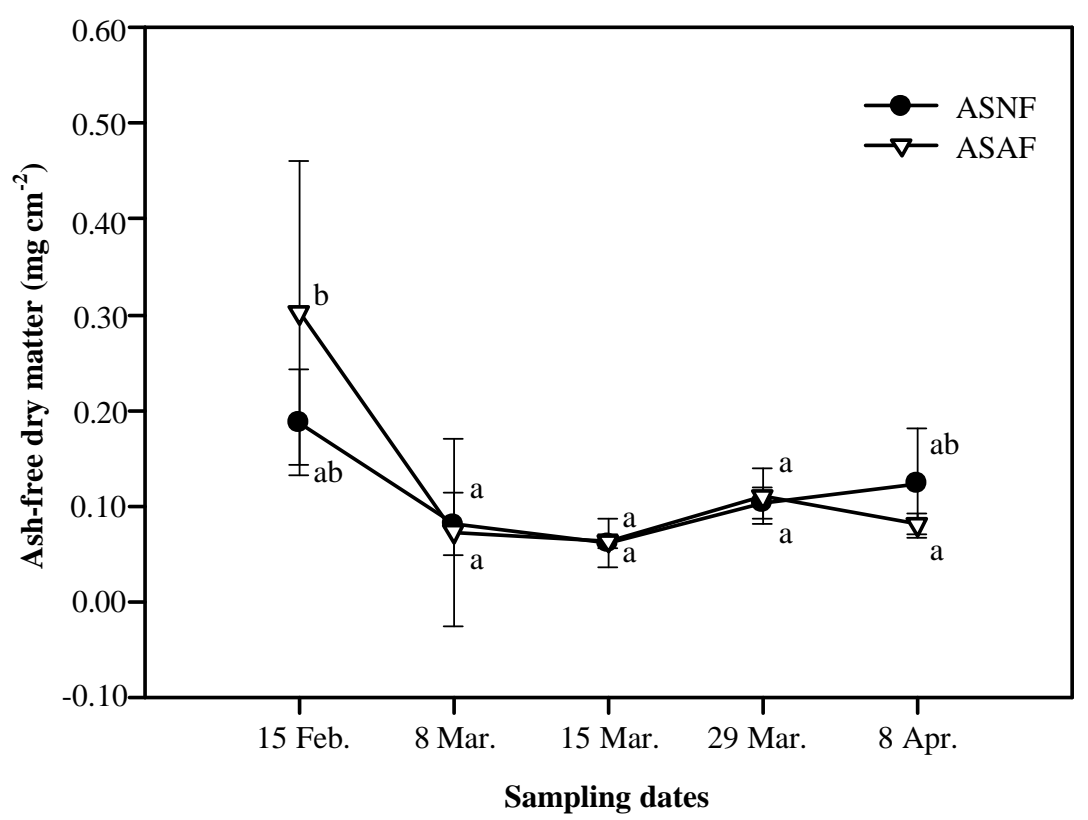

Figure 2. Average periphyton ash free dry matter during the experimental period. Values are the means $\pm \mathrm{SD}$ of three replicated cages per sampling date $(n=3)$ in each treatment.

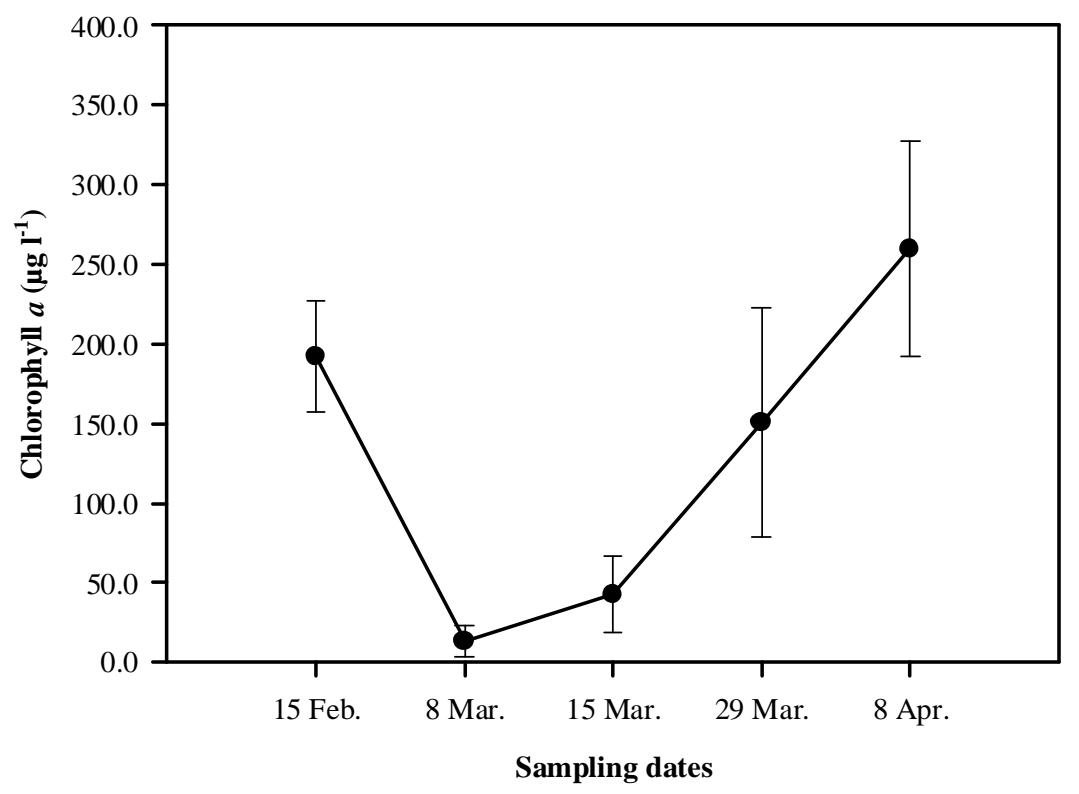

Figure 3. Average chlorophyll $a$ concentration of water column in different treatments during the experimental period. Values are the means $\pm S D$ of three replicated cages per sampling date $(n=3)$ in each treatment. 
Table 3. Average water quality parameters measured in cages and in open pond water during experiment. All values are means $\pm \mathrm{SD}$

\begin{tabular}{lll}
\hline Parameters & $\begin{array}{l}\text { Inside cages } \\
(\mathrm{n}=48)\end{array}$ & $\begin{array}{l}\text { In open pond } \\
(\mathrm{n}=12)\end{array}$ \\
\hline Dissolved oxy gen $(\mathrm{mg} / \mathrm{L})$ & $4.30 \pm 1.19$ & $4.48 \pm 1.15$ \\
$\mathrm{pH}$ & $8.87 \pm 0.44$ & $8.79 \pm 0.46$ \\
Conductivity $(\mu \mathrm{S} / \mathrm{cm})$ & $252.4 \pm 32.3$ & $262.2 \pm 49.6$ \\
Temperature $\left({ }^{0} \mathrm{C}\right)$ & $26.81 \pm 1.65$ & $26.70 \pm 1.68$ \\
Total ammonia $(\mathrm{mg} / \mathrm{L})$ & $0.16 \pm 0.02$ & $0.15 \pm 0.03$ \\
Nitrite-nitrogen $(\mathrm{mg} / \mathrm{L})$ & $0.25 \pm 0.28$ & $0.28 \pm 0.31$ \\
Nitrate-nitrogen $(\mathrm{mg} / \mathrm{L})$ & $1.50 \pm 1.70$ & $1.54 \pm 1.70$ \\
Total nitrogen $(\mathrm{mg} / \mathrm{L})$ & $3.29 \pm 1.57$ & $3.41 \pm 1.57$ \\
Soluble reactive $\mathrm{phosphorus}(\mathrm{mg} / \mathrm{L})$ & $0.91 \pm 0.54$ & $0.93 \pm 0.54$ \\
Total phosphorous $(\mathrm{mg} / \mathrm{L})$ & $1.62 \pm 0.46$ & $1.72 \pm 0.53$ \\
Total alkalinity $(\mathrm{mg} / \mathrm{L})$ & $156.75 \pm 19.16$ & $157.71 \pm 21.14$ \\
Total hardness $(\mathrm{mg} / \mathrm{L})$ & $127.60 \pm 2.62$ & $128.35 \pm 2.44$ \\
\hline
\end{tabular}

complement supplemental feeding in net cage culture system. This finding is different from a study on the effects of bamboo substrates and supplemental feeding on the growth and production of hybrid red tilapia fingerlings which was conducted in ponds. In that experiment it was found that periphyton could replace or complement supplemental feeding in tilapia fingerling culture (Keshavanath et al., 2004).

In the present study, the survival rates of the fish from all treatments ranged from 83 - 96\% which was higher than that of a previous study by Little et al. (2003) on advanced nursing of mixed-sex and monosex tilapia fry in hapas. In that experiment, the survival rates among all of the treatment groups ranged from $69-86 \%$. Additionally, that study found that the specific growth rate of Nile tilapia fry (initial mean weight $0.13 \mathrm{~g}$ ) raised in hapas suspended in fertilized pond at a stocking density of 150 $\mathrm{fish} / \mathrm{m}^{2}$ with supplementary feeds (a mixture of layer-duck concentrate manufactured by Charoen Pokphand Co. and fine rice bran, 2: 1 ratio by volume) at $5 \%$ daily ration for a 2-month period was $6.2 \% /$ day (Little et al., 2003). While, a higher specific growth rate
(6.82 \%/day) was obtained from NSNF treatment in the present study.

However the use of periphyton in aquaculture is based on the finding that many herbivorous fish prefer feeding on benthic, epilithic or periphytic algae, rather than on small phytoplankton (Horn, 1989; van Dam et al., 2002). Beveridge and Baird (2000) have shown that Nile tilapia is a periphyton grazer although tilapias have been primarily described as filter feeders on phytoplankton (Moriarty and Moriarty, 1973; Bocci, 1999). Stomach content analysis of tilapias grown in cages in the Meghna River showed that they were both filter feeders and grazers (Hutchette et al., 2000). The proportion of each feeding mode was difficult to determine, but a visual estimate of gut contents suggested a higher contribution from periphyton (Huchette and Beveridge, 2003). However, a filter feeding mechanism can occur naturally during fish respiration whilst the intake of supplementary feed or periphyton is rather selective feeding. Therefore, when filter feeding can serve their nutritional requirements, then the fish will not feed selectively on other food sources. 
The results from an earlier periphytonbased cage experiment showed that the average AFDM of periphyton in the uppermost $50 \mathrm{~cm}$ of the water column was $0.36 \mathrm{mg} / \mathrm{cm}^{2}$ (Huchette and Beveridge, 2003). This value is high when compared to the average periphyton AFDM throughout the culture period in the present study of $0.12 \mathrm{mg} / \mathrm{cm}^{2}$. However, when the periphyton biomass in the present study of $0.24 \mathrm{mg} / \mathrm{cm}^{2}$ before fish stocking is considered, a significant decrease in periphyton biomass after fish stocking indicated that the fish consumed periphyton, while no significant difference in periphyton biomass between ASNF and ASAF treatments for each sampling day may indicate the same grazing rate for both groups of the fish. But no significant difference in growth performances was observed among the treatments, were provided with substrate or not indicating that addition of substrate at approximately equal to cage surface area was not sufficient for significantly increasing in periphyton production. Because the ash $(10-19 \%)$, protein $(23-26 \%)$ and energy $(19-20$ $\mathrm{KJ} / \mathrm{g}$ ) contents of the estimated periphyton can be considered as broadly appropriate to fish dietary needs (Azim et al., 2002b). While crude protein content of the supplementary feed in the present study was approximately $27.7 \%$.

Yields obtained in extensive cage aquaculture in the Philippines range from 0.05 to $1.25 \mathrm{~kg} / \mathrm{m}^{3} / \mathrm{month}$ without input (Beveridge, 1996), and are in agreement with a study on technical and economical evaluation of periphyton-based cage culture of tilapia (Oreochromis niloticus) in tropical freshwater cages which gave yields of 0.12 to $0.24 \mathrm{~kg} / \mathrm{m}^{3} / \mathrm{month}$ (Huchette and Beveridge, 2003). The fish gross yields obtained from NSNF treatment in the present study was $1.22 \mathrm{~kg} / \mathrm{m}^{3}$ for the 56-day period, which is equivalent to 0.61 $\mathrm{kg} / \mathrm{m}^{3} /$ month. The values were higher than those of the previous studies. Even the difference was clearly due to different growth phase of the experimental fish. However, the results show the potential use of extensive cage net cage culture in nutrient-enriched water bodies; e.g. aquaculture ponds, communal water bodies and nutrient-enriched lakes; particularly for Nile tilapia fingerling production. Base on the results, it may be concluded that adding substrates, which give an additional submerged surface area approximately equal to the total cage surface area is not sufficient for periphyton production, and for good growth of Nile tilapia fingerling net cage culture system. And even supplementary feeding gave a higher yield when compared to no feeding cages, but either provision of substrates or supplementary feed could lead to higher production cost. In the present study, final weight of the fish from all treatments ranged from $2.8-5.2 \mathrm{~g}$, and this final weight is not likely to affect market price of the fingerlings. In the present study, initial stocking density of the fish was 500 fish $/ \mathrm{m}^{3}$; however, reducing fish density may increase growth of the fish. Because the availability of natural food could decrease at the high fish densities and possibly result in nutrition deficiencies (Coulibaly et al., 2007). In conclusion, an extensive net cage culture in nutrient-enriched pond shows a high potential in early nursing of Nile tilapia.

\section{Acknowledgements}

The Aquatic Animals Research Center, Nong Khai campus, Khon Kaen University are acknowledged for the provision of 


\section{W. Jiwyam / Our Nature (2012) 10: 61-70}

materials, equipments and research facilities. The author also thanks Mr. Punya Dachrat and Miss. Nisarat Tippayadara, School of Sciences and Technology, Nong Khai Campus, Khon Kaen University, for their excellent technical assistances during the course of the experiment.

\section{References}

AOAC. 2005. Official methods of analysis of AOAC international. $18^{\text {th }}$ edn. Gaithersburg, Maryland, USA, AOAC International.

APHA. 1989. Standard methods for the examination of water and wastewater. $17^{\text {th }}$ edn. American Public Health Association, Washington, DC.

Azim, M. E., M. A. Wahab, A. A. van Dam, M. C. M. Beveridge and M. C. J. Verdegem. 2001a. The potential of periphyton-based culture of two Indian major carps, rohu Labeo rohita and gonia Labeo gonius (Linnaeus). Aquac. Res. 32: 209216.

Azim, M. E., M. A. Wahab, A. A. van Dam, M. C. M. Beveridge, E. A. Huisman and M. C. J. Verdegem. 2001b. Optimization of stocking ratios of two Indian major carps, rohu (Labeo rohita Ham.) and catla (Catla catla Ham.) in a periphyton-based aquaculture system. Aquaculture 203: 33-49.

Azim, M. E., M. C. J. Verdgem, M. M. Rahman, M. A. Wahab, A. A. van Dam and M. C. M. Beveridge. 2002a. Evaluation of polyculture of Indian major carps in periphyton-based ponds. Aquaculture 213: 131-149.

Azim, M. E., M. A. Wahab, M. C. J. Verdegem, A. A. van Dam, J. M. van Rooij and M. C. M. Beveridge. 2002b. The effects of artificial substrates on freshwater pond productivity and water quality and the implications for periphytonbased aquaculture. Aquat. Liv. Resour. 15: 231241.

Beveridge, M. C. M. 1996. Cage aquaculture. $2^{\text {nd }} \mathrm{edn}$. Fishing News, Oxford.

Beveridge, M. C. M. and D. J. Baird. 2000. Diet, feeding and digestive physiology. In: Tilapia: Biology and exploitation (Eds. M.C.M Beveridge and B.J. McAndrew), Kluwer Academic Publishing, Dordrecht, Netherlands. pp. 59-87.

Bocci, M. 1999. Modelling the growth of Nile tilapia (Oreochromis niloticus) feeding on natural resources in enclosures in Laguna de Bay (Philippines). Ecol. Model. 119: 135-148.
Bowen, S. H. 1981. Digestion and assimilation of periphytic detrital aggregate by Tilapia mossambica. Trans. Amer. Fish. Soc. 110: 239245.

Bowen, S. H. 1982. Feeding, digestion and growthqualitative considerations. In: The Biology and Culture of Tilapias, vol. 7. (Eds. R. S. V. Pullin and R. H. Lowe-McConnell), ICLARM Conf. Proc., Int. Center for Living Aquatic Resources Management, Manila, Philippines. pp. 141-156.

Boyd, C. E. 1982. Water quality management for pondfish culture. Elsevier, Amsterdam.

Boyd, C. E. and C. S. Tucker. 1992. Water quality and pond soil analyses for aquaculture. Auburn University, AL.

Coulibaly, A., I. N. Ouattara, T. Koné, V. N'Douba, J. Snoeks, B. G. Gooré and E. P. Kouamélan. 2007. First results of floating cage culture of the African catfish Heterobranchus longifilis Valenciennes, 1840: Effect of stocking density on survival and growth rates. Aquaculture 263: 61-67.

El-Sayed, A.F.M, S. I. Teshimab. 1992. Protein and energy requirements of Nile tilapia, Oreochromis niloticus, fry. Aquaculture 103 (1): 55-63.

Hem, S. and J. L. B. Avit. 1994. First results on 'acadjas enclos'as an extensive aquaculture system (West Africa). Bull. Mar. Sci. 55: 10381049.

Hepher, B. 1988. Nutrition of pond fishes. Cambridge University Press.

Horn, M. H. 1989. Biology of marine herbivorous fishes. Oceanogr. Mar. Biol. Ann. Rev. 27: 167272.

Huchette, S. M. H., M. C. M. Beveridge, D.J. Baird and M. Ireland. 2000. The impacts of grazing by tilapias (Oreochromis niloticus L.) on periphyton communities growing on artificial substrate in cages. Aquaculture 186: 45-60.

Huchette, S. M. H. and M. C. M. Beveridge. 2003. Technical and economical evaluation of periphyton-based cage culture of tilapia (Oreochromis niloticus) in tropical freshwater cages. Aquaculture 218: 219-234.

Keshavanath, P., B. Ganghadar, T. J. Ramesh, J. M. Van Rooij, M. C. M. Beveridge, D. J. Baird, M. C. J. Verdegem and A. A. van Dam. 2001a. The potential of artificial reefs to enhance production of herbivorous fish in Indian freshwater pondspreliminary trials. Aquac. Res. 32: 189-197.

Keshavanath, P., B. Ganghadar, T. J. Ramesh, J. M. Van Rooij, M. C. M. Beveridge, D. J. Baird, M. C. J. Verdegem and A. A. van Dam. 2001b. Use of 


\section{W. Jiwyam / Our Nature (2012) 10: 61-70}

artificial substrates to enhance production of freshwater herbivorous fish in pond culture. Aquac. Res. 32 (3): 189-197.

Keshavanath, P., B. Gangadhar, T. J. Ramesh, A. A van Dam, M. C. M. Beveridge and M. C. J. Verdegem. 2002. The effect of periphyton and supplemental feeding on the production of the indigenous carps Tor khudree and Labeo fimbriatus. Aquaculture 213: 207-218.

Keshavanath, P., B. Gangadhar, T. J. Ramesh, A. A. van Dam, M. C. M. Beveridge and M. C. J. Verdegem. 2004. Effects of bamboo substrate and supplemental feeding on growth and production of hybrid red tilapia fingerlings (Oreochromis mossambicus X Oreochromis niloticus). Aquaculture 235: 303-314.

Little, D.C., R. C. Bhujel and T. A. Pham. 2003. Advanced nursing of mixed-sex and mono-sex tilapia (Oreochromis niloticus) fry, and it impact on subsequent growth in fertilized ponds. Aquaculture 221: 265-276.

Moriarty, C. M. and D. J. Moriarty. 1973. Quantitative estimation of the daily ingested of phytoplankton by Tilapia nilotica and Haplochromis nigripinnis in Lake George, Uganda. J. Zool. (London) 171: 15-23.
Norberg, J. 1999. Periphyton fouling as a marginal energy source in tropical tilapia cage farming. Aquac. Res. 30: 427-430.

Ramesh, M. R., K. M. Shankar, C. V. Mohan and T. J. Varghese. 1999. Comparison of three plant substrates for enhancing carp growth through bacterial biofilm. Aquac. Eng. 19: 119-131.

Shrestha, M. K. and C. F. Knud-Hansen. (1994) Increasing attached microorganisms biomass as a management strategy for Nile tiapia (Oreochromis niloticus) production. Aquac. Eng. 13: 101-108.

Uddin, M. S. 2007. Mixed Culture of Tilapia (Oreochromis niloticus) and Freshwater Prawn (Macrobrachium rosenbergii) in Periphyton-based Ponds. PhD Thesis, Wageningen University, The Netherlands.

van Dam A. A., M. C. M. Beveridge, M. E. Azim and M. C. J. Verdegem. 2002. The potential of fish production based on periphyton. Rev. Fish Biol. Fish. 12: 1-31.

Wahab, M. A., M. E. Azim, M. H. Ali, M. C. M. Beveridge and S. Khan. 1999. The potential of periphyton-based culture of the native major carp calbaush, Labeo calbasa (Hamilton). Aquac. Res. 30: 409-419. 